\title{
FAKTOR STRATEJIK HASIL BELAJAR MATEMATIKA SISWA DI SEKOLAH MENEGAH PERTAMA
}

\author{
Sutama, Nugraheni Nur Janah, dan Meggy Novitasari \\ Pendidikan Matematika \\ Universitas Muhammadiyah Surakarta \\ sutama@ums.ac.id,nugraheni_nurj@yahoo.com,meggy151013@gmail.com
}

\begin{abstract}
The aims of this study are to examine the contribution of the teacher's appearance in the learning, motivation, and facilities towards mathematics learning with mediation of discipline learning. The type of this study is quantitative casual correlation. The population are 190 students grade VII Junior High School of Salatiga 6 in academic year 2016/2017. Sampling are 128 students assigned to the Slovin formula (. Sampling technique is proportional random sampling by lottery. Data collection used documentation and questionnaire. Analysis technique used path analysis. The results are (1) there is a contribution of the teacher appearance in the learning, motivation, and facilities towards mathematics learning outcome with mediation of discipline learning $(10 \%$, sig. $=0,000)$, (2) the teacher appearanve in the learning to contribution in pearson towards mathematics learning outcome is $(0,54 \%$, sig $=0,412)$. Motivation learning to contribution is not direcly towards mathematics learning outcomes through discipline learning $(22,1 \%$, sig $=0,000)$, (3) facilities learning contributes in pearson towars mathematics learning outcome $(0,0009 \%$, sig = 0,997). As a conclusion, mathematics learning outcome of Junior High School supports the teacher's appearance in the learning, motivation, and facilities with mediation of discipline learning.
\end{abstract}

Keyword: facilities, learning outcomes, discipline learning, motivation, appearance of teacher

\begin{abstract}
Abstrak. Tujuan penelitian ini adalah menguji kontribusi penampilan guru dalam pembelajaran, motivasi, dan fasilitas terhadap hasil belajar matematika dengan mediasi kedisiplinan belajar. Jenis penelitian ini adalah kuantitatif korelasional kausal. Populasi penelitian sejumlah 190 siswa kelas VII Sekolah Menengah Pertama Negeri 6 Salatiga tahun 2016/2017. Sampel penelitian sejumlah 128 siswa ditentukan dengan rumus Slovin $(\alpha=0,05)$. Teknik sampling, proporsional random sampling dirtentukan dengan undian. Data dikumpulkan dengan dokumentasi dan angket. Teknik analisis data menggunakan analisis jalur. Hasil penelitian menunjukkan ada kontribusi penampilan guru dalam pembelajaran, motivasi, dan fasilitas terhadap hasil belajar matematika dengan mediasi kedisiplinan belajar $(10 \%$, sig. =0,011). Penampilan guru dalam pembelajaran berkontribusi secara langsung terhadap hasil belajar matematika $(0,54 \%$, sig. = 0,412). Motivasi belajar berkontribusi secara tidak langsung terhadap hasil belajar matematika melalui kedisiplinan belajar $(22,1 \%$, sig. $=0,000)$. Fasilitas belajar berkontribusi secara langsung terhadap hasil belajar matematika $(0,0009 \%$, sig. = 0.997). Kesimpulan dari penelitian ini adalah pembelajaran matematika di Sekolah Menengah Pertama menjadi baik karena
\end{abstract}


dukungan dari penampilan guru dalam pembelajaran, motivasi, dan fasilitas dengan mediasi kedisiplinan belajar.

Kata kunci: fasilitas, hasil belajar, kedisiplinan belajar, motivasi, penampilan guru

\section{Pendahuluan}

Hasil belajar merupakan salah satu indikator dalam melihat ketercapaian tujuan pembelajaran matematika di sekolah. Hasil belajar menurut Prianto (2013) adalah kemampuan yang dimiliki siswa setelah ia menerima pengalaman belajarnya (dari tidak tahu dan dari tidak mengerti menjadi mengerti). Selain itu, hasil belajar menurut Suhendri (2011) adalah puncak dari kegiatan belajar yang berupa perubahan dalam bentuk kognitif, afektif dan psikomotorik dalam hal kemampuan tentang bilangan, bangin, hubungan-hubungan konsep dan logika yang berkesinambungan serta dapat diukur atau diamati.

Hasil belajar matematika penting seperti diuraikan tersebut, namun realitanya belum sesuai harapan. Oleh karena itu, diperlukan suatu cara untuk meningkatkan hasil belajar matematika. Bervariasinya hasil belajar matematika dapat disebabkan oleh beberapa faktor. Faktor-faktor tersebut yaitu bersumber dari siswa, alat dan lingkungan. Faktor yang bersumber dari siswa adalah motivasi dan kedisiplinan. Motivasi adalah dorongan yang menyebabkan terjadinya suatu perbuatan guna mencapai suatu tujuan. Motivasi belajar yaitu suatu dorongan atau kemauan seseorang untuk melakukan aktivitas belajar agar prestasi belajar dapat dicapai. Kedisiplinan pengembangan tabiat individu dalam melaksanakan peraturan-peraturan yang belaku baik secara langsung maupun tidak langsung.

Faktor yang berasal dari alat yaitu fasilitas. Menurut Sawiji (2012) fasilitas merupakan komponen yang bersumber pada barang-barang hasil produksi yang antara lain berupa alat pembelajaran sarana dan gedung beserta perlengkapannya sebagai prasarana yang berfungsi menyediakan tempat berlangsungnya proses pendidikan.
Sedangkan faktor dari lingkungan yaitu penampilan guru dalam pembelajaran. Penampilan adalah aplikasi dari kemauan kerja dalam wujud nyata dan tindakan. Penampilan merupakan ciri pertama yang perlu ada bagi guru ketika di dalam kelas. Penampilan yang di tampilkan oleh guru dalam proses pembelajaran akan diamati, dilihat dan dinilai oleh siswa. Penampilan guru yang baik akan lebih mampu menciptakan lingkungan belajar yang efektif dan mampu mengelola proses pembelajaran. Adapun penelitian terdahulu dari Daud (2012) menyatakan bahwa motivasi belajar berpengaruh positif dan signifikan terhadap hasil belajar. Muyiwa \& Quadri (2012) meyatakan bahwa fasilitas berpengaruh terhadap prestasi siswa karena fasilitas dapat dimanfaatkan siswa untuk memperoleh pengetahuan, keterampilan, sikap, yang meliputi grafis, fotografi elektronik seperti alat mekanis yang menangkap, memproses dan membangun kembali informasi visual dan verbal. Cahyadi (2016) menyatakan bahwa ada hubungan antara motivasi belajar siswa dan penampilan guru dengan hasil belajar. Prasojo (2014) menyatakan bahwa kedisiplinan belajar mempunyai pengaruh positif signifikan terhadap preatasi belajar mata pelajaran IPS siswa kelas VIII Mts Maftahul Falah.

Bertolak dari uraian di atas, penelitian ini bertujuan untuk menguji kontribusi penampilan guru dalam pembelajaran, motivasi dan fasilitas terhadap hasil belajar matematika secara tidak langsung dengan kedisiplinan belajar.

\section{Metode}

Jenis penelitian ini, yaitu kuantitatif korelasional kausal. Penelitian ini dilaksanakan di SMP Negeri 6 Salatiga. Penelitian dilaksanakan pada semester genap 
tahun ajaran 2016/2017. Populasi penelitian siswa kelas VII sebanyak 190 siswa. Jumlah sampel penelitian ini 128 siswa yang ditentukan dengan rumus Slovin $(\alpha=0,05)$. Teknik pengambilan sampel menggunakan proporsional random sampling dengan cara undian. Variabel independen dalam penelitian ini, yaitu penampilan guru dalam pembelajaran $\left(X_{1}\right)$, motivasi belajar $\left(X_{2}\right)$, dan fasilitas belajar $\left(X_{3}\right)$, variabel intervening kedisiplinan belajar $(Y)$, dan variabel independennya, yaitu hasil pembelajaran matematika $(Z)$.

Teknik pengumpulan data menggunakan metode dokumentasi dan angket (Sutama, 2015: 148). Instrumen penelitian di uji coba dengan menggunakan uji validitas item dan uji reliabilitas angket. Teknik analisis data menggunakan analisis jalur. Teknik analisis jalur digunakan dalam menguji besarnya kontribusi yang ditunjukkan oleh koefisien jalur pada setiap diagram jalur dari hubungan kausal antara variabel eksogen $X_{1}, X_{2}$, dan $X_{3}$ terhadap variabel endogen $Y$ dan $Z$ (Ridwan $\&$ Kuncoro, 2013: 5). Sebelum analisis data, dilakukan uji prasyarat analisis, yaitu uji normalitas, uji linieritas, uji multikolonieritas, uji heteroskedastisitas, dan uji autokorelasi.

\section{Hasil dan Pembahasan}

Instrumen angket sebelumnya diuji cobakan pada 30 siswa dalam populasi selain sampel penelitian. Data hasil coba instrumen untuk menguji validitas item dan reliabilitas angket. Uji validitas item pernyataan menggunakan korelasi product moment. Nilai korelasi dari masing-masing item pernyataan pada sampel uji coba sebanyak 30 siswa dengan nilai koefisien korelasi tabel yaitu 0,3494 dengan taraf signifikansi 0,05.

Hasil uji validitas instrumen angket kedisiplinan belajar sebanyak 9 item pernyataan diperoleh $r_{\text {hitung }} r_{\text {tabel }}$ yaitu 0,3494 (lima item tidak valid tidak digunakan). Hasil uji validitas instrumen angket penampilan guru dalam pembelajaran sebanyak 5 item pernyataan diperoleh $r_{\text {hitung }} r_{\text {tabel }}$ yaitu 0,3494 (satu item tidak valid tidak digunakan). Hasil uji validitas instrumen angket motivasi belajar sebanyak 7 item pernyataan diperoleh $r_{\text {hitung }}$ $r_{\text {tabel }}$ yaitu 0,3494 (satu item tidak valid tidak diguakan). Hasil uji validitas fasilitas belajar sebanyak 26 item pernyataan $r_{\text {hitung }} r_{\text {tabel }}$ yaitu 0,3494 (dua item tidak valid tidak digunakan). Hal in berarti dalam varibel independen 9,5,7,26 item valid, layak digunakan untuk mengumpulkan data.

Item-item pernyataan yang digunakan untuk mengumpulkan data pada masingmasing variabel penampilan guru dalam pembelajaran, motivasi belajar, fasilitas belajar, dan kedisiplinan belajar diuji reliabilitas menggunakan rumus Cronbach's Alpha. Ringkasan hasil uji reliabilitas angket pad masing-masing variabel dependen disajikan pada Tabel 1.

Tabel 1. Hasil Uji Reliabilitas Angket

\begin{tabular}{lc}
\hline \multicolumn{1}{c}{ Variabel } & $\begin{array}{c}\text { Cronbach's } \\
\text { Alpha }\end{array}$ \\
\hline $\begin{array}{l}\text { Kedisiplinan Belajar (Y) } \\
\text { Penampilan Guru Dalam Pem- } \\
\text { belajaran (X1) }\end{array}$ & 0,832 \\
Motivasi (X2) & 0,582 \\
Fasilitas (X3) & 0,791 \\
\hline
\end{tabular}

Hasil belajar matematika diperoleh dengan menggunakan metode dokumentasi yaitu hasil Ujian Tengah Semester Gasal tahun ajaran 2016/2017 SMP Negeri 6 Salatiga. Berdasarkan data yang diperoleh nilai tertinggi 96 , nilai terendah 35 dengan rata-rata 58.976 sebesar dan standar deviasi 14.376. Klasifikasi nilai yaitu 22 siswa atau $17.18 \%$ dari 128 sampel dalam kategori hasil belajar matematika tinggi 82 siswa atau $64.06 \%$ dari 128 sampel dalam kategori hasil belajar matematika sedang, dan 24 siswa atau $18.75 \%$ dari 128 sampel dalam kategori hasil belajar rendah.

Kedisiplinan diperoleh dari angket yang terdiri dari 14 item pernyataan. Berdasarkan data diperoleh nilai tertinggi 44 dan nilai terendah 17 dengan rata-rata sebesar 31.687 dan standar deviasi 5.075 Klasifikasi nilai yaitu 19 siswa atau $14.84 \%$ dari 128 sampel 
dalam kategori kedisiplinan belajar tinggi, 88 siswa atau $68.75 \%$ dari 128 sampel dalam kategori kedisiplinan sedang, dan 21 siswa atau $16.41 \%$ dari 128 sampel dalam kategori kedisiplinan rendah.

Penampilan guru dalam pembelajaran diperoleh dari angket yang terdiri dari 5 item pernyataan. Berdasarkan data diperoleh nilai tertinggi 25 dan nilai terendah 9 dengan ratarata sebesar 20.383 dan standar deviasi 2.668. Klasifikasi nilai yaitu 13 siswa atau $10.16 \%$ dari 128 sampel dalam kategori penampilan guru dalam pembelajaran tinggi, 96 siswa atau $75 \%$ dari 128 sampel dalam kategori penampilan guru dalam pembelajaran sedang, dan 19 siswa atau $14.84 \%$ dari 128 sampel dalam kategori penampilan guru dalam pembelajaran rendah.

Motivasi belajar diperoleh dari angket yang terdiri dari 7 item pernyataan. Berdasarkan data diperoleh nilai tertinggi 35 dan nilai terendah 11 dengan rata-rata sebesar 26.312 dan standar deviasi 5.324. Klasifikasi nilai yaitu 19 siswa atau $14.84 \%$ dari 128 sampel dalam kategori motivasi tinggi, 88 siswa atau $68.75 \%$ dari 128 sampel dalam kategori motivasi sedang, dan 21 siswa atau $16.41 \%$ dari 128 sampel dalam kategori motivasi rendah.

Fasilitas belajar diperoleh dari angket yang terdiri dari 26 item pernyataan. Berdasarkan data diperoleh nilai tertinggi 150 dan nilai terendah 54 dengan rata-rata sebesar 97.5625 dan standar deviasi 16.982. Klasifikasi nilai yaitu 22 siswa atau $17.19 \%$ dari 128 sampel dalam kategori fasilitas tinggi, 83 siswa atau $64.84 \%$ dari 128 sampel dalam kategori fasilitas sedang, dan 23 siswa atau $17.97 \%$ dari 128 sampel dalam kategori fasilitas rendah. Rincian masing-masing kategori variabel disajikan dalam Gambar 1.

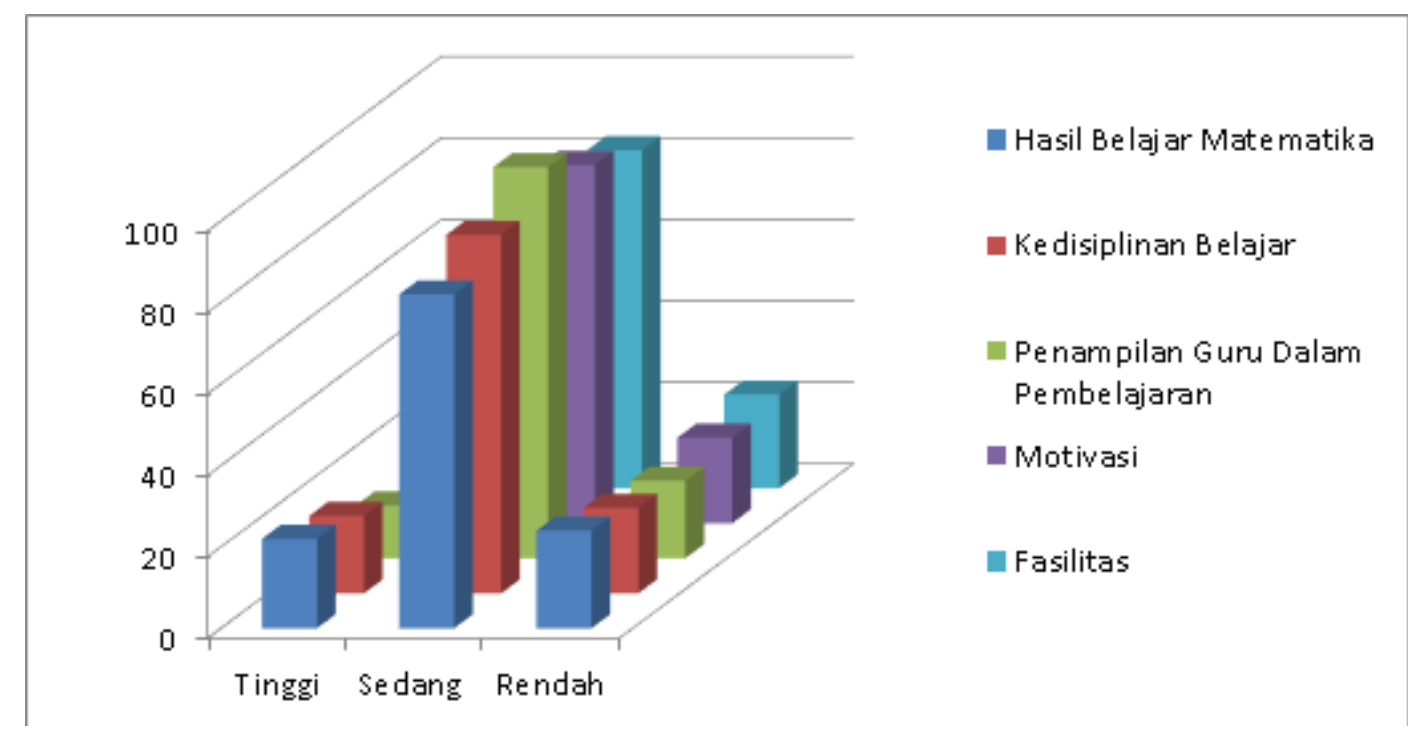

Gambar 1. Diagram Batang Masing-Masing Data Variabel Penelitian

Tabel 2. Hasil Uji Normalitas

\begin{tabular}{lcc}
\hline \multicolumn{1}{c}{ Variabel } & Sig & Keterangan \\
\hline Hasil Belajar Matematika (Z) & 0.499 & Normal \\
Kedisiplinan Belajar (Y) & 0.088 & Normal \\
Penampilan Guru Dalam Pembelaja- & 0.068 & Normal \\
ran (X1) & & \\
Motivasi (X2) & 0.452 & Normal \\
Fasilitas (X3) & 0.797 & Normal \\
\hline
\end{tabular}


Tabel 3. Hasil Uji Linieritas

\begin{tabular}{cccc}
\hline \multirow{2}{*}{ Variabel } & \multicolumn{2}{c}{ Harga $\mathbf{F}$} & \multirow{2}{*}{ Keterangan } \\
\cline { 2 - 3 } & $\mathbf{F}_{\text {hitung }}$ & $\mathbf{F}_{\text {tabel }}$ & \\
\hline $\mathrm{X}_{1}$ terhadap Y & 1.800 & 1.838 & Linier \\
$\mathrm{X}_{2}$ terhadap Y & 0.514 & 1.645 & Linier \\
$\mathrm{X}_{3}$ terhadap Y & 1.239 & 1.513 & Linier \\
$\mathrm{X}_{1}$ terhadap Z & 1.318 & 1.838 & Linier \\
$\mathrm{X}_{2}$ terhadap Z & 0.727 & 1.645 & Linier \\
$\mathrm{X}_{3}$ terhadap Z & 1.247 & 1.513 & Linier \\
\hline
\end{tabular}

Tabel 4. Hasil Uji Multikolonieritas

\begin{tabular}{|c|c|c|c|}
\hline \multirow{2}{*}{ Variabel } & \multicolumn{2}{|c|}{ Nilai } & \multirow{2}{*}{ Keterangan } \\
\hline & TOL & VIF & \\
\hline$X_{1} \operatorname{dan} X_{2}$ & 0.987 & 1.013 & Tidak Multikolonieritas \\
\hline $\mathrm{X}_{1} \operatorname{dan} \mathrm{X}_{3}$ & 0.934 & 1.071 & Tidak Multikolonieritas \\
\hline$X_{2} \operatorname{dan} X_{3}$ & 0.990 & 1.010 & Tidak Multikolonieritas \\
\hline
\end{tabular}

Tabel 5. Hasil Uji Heteroskedastisitas

\begin{tabular}{ccc}
\hline Variabel & P-Value & Keterangan \\
\hline $\mathrm{X}_{1}$ terhadap Y & 0.460 & Tidak Heteroskedastisitas \\
$\mathrm{X}_{2}$ terhadap Y & 0.117 & Tidak Heteroskedastisitas \\
$\mathrm{X}_{3}$ terhadap Y & 0.221 & Tidak Heteroskedastisitas \\
$\mathrm{X}_{1}$ terhadap Z & 0.531 & Tidak Heteroskedastisitas \\
$\mathrm{X}_{2}$ terhadap Z & 0.324 & Tidak Heteroskedastisitas \\
$\mathrm{X}_{3}$ terhadap Z & 0.866 & Tidak Heteroskedastisitas \\
\hline
\end{tabular}

Tabel 6. Hasil Uji Autokorelasi

\begin{tabular}{|c|c|c|c|c|c|}
\hline \multirow{2}{*}{ Variabel } & \multirow{2}{*}{ DW } & \multicolumn{3}{|c|}{ D-Tabel } & \multirow{2}{*}{ Keterangan } \\
\hline & & $\mathrm{Dl}$ & $\overline{\mathrm{Du}}$ & 4-Du & \\
\hline $\begin{array}{c}\mathrm{X}_{1}, \mathrm{X}_{2}, \operatorname{dan} \mathrm{X}_{3} \\
\text { terhadap } \mathrm{Y}\end{array}$ & 1.938 & 1.6623 & 1.7589 & 2.2411 & $\begin{array}{l}\text { Tidak Ada } \\
\text { Autokorelasi }\end{array}$ \\
\hline $\begin{array}{c}X_{1}, X_{2} \text {, dan } X_{3} \\
\text { terhadap } Z\end{array}$ & 1.773 & 1.6623 & 1.7589 & 2.2411 & $\begin{array}{c}\text { Tidak Ada } \\
\text { Autokorelasi }\end{array}$ \\
\hline
\end{tabular}

Tabel 7. Direct and Indirect

\begin{tabular}{cccc}
\hline & \multicolumn{2}{c}{ Pengaruh Kausal } & Sisa \\
\cline { 2 - 3 } Pengaruh Variabel & Langsung & $\begin{array}{c}\text { Tidak Langsung } \\
\text { Melalui Y }\end{array}$ & \\
\hline $\mathrm{X}_{1}$ Terhadap Z & - & - & - \\
$\mathrm{X}_{2}$ Terhadap Z & - & - & - \\
& & - & - \\
$\mathrm{X}_{3}$ Terhadap Z & - & - & - \\
$\mathrm{X}_{1}, \mathrm{X}_{2}, \mathrm{X}_{3,}$ YTerhadap Z & $10 \%$ & - & $90 \%$ \\
\hline
\end{tabular}


Sebelum dilakukan analisis data dengan analisis jalur dilakukan uji prasyarat analisis. Uji normalitas dengan KolmogorovSmirnov $(K-S)$. Data berdistribusi normal apabila nilai sig $>0.05$ dan data tidak berdistribusi normal apabila nilai sig $<0.05$. Data dalam penelitian ini berdistribusi normal karena nilai sig masing-masing variabel lebih dari 0.05. Adapun ringkasan hasil pengujian terdapat pada tabel 2 berikut.

Uji linieritas dengan uji $\mathrm{F}$, dikatakan linier apabila $F_{\text {hitung }} F_{\text {tabel }}$ dan tidak linier apabila $\mathrm{F}_{\text {hitung }} \mathrm{F}_{\text {tabel. }}$. Data dalam penelitian ini mempunyai hubungan yang linier karena $\mathrm{F}_{\text {hitung }} \mathrm{F}_{\text {tabel }}$. Adapun ringkasan hasil pengujian terdapat pada Tabel 3 .

Uji multikolonieritas dapat dilihat dari nilai Variance Inflation Factor (VIF) dan Tolerance (TOL). Tidak ada gejala multikolonieritas apabila dan 0.1. Terjadi multikolonieritas apabila dan 0.1. Data dalam penelitian ini tidak ada gejala multikolonieritas karena VIF $<10$ dan TOL $>$ 0.1 . Adapun ringkasan hail pengujian terdapat pada Tabel 4.
Uji heteroskedastisitas pada penelitian ini menggunakan uji glejser. Apabila nilai signifikansi, maka tidak ada masalah heteroskedastisitas dan terjadi heteroskedastisitas apabila nilai signifikansi . Dalam penelitian ini tidak terjadi masalah heteroskedastisitas karena nilai signifikansi $>0.05$. Adapun ringkasan hasil pengujian terdapat pada Tabel 5 berikut.

Uji autokorelasi pada penelitian ini menggunakan uji Durbin-Watson. Apabila nilai Durbin-Watson lebih dari Du dan kurang dari 4-du maka tidak ada autokorelasi. Data dalam penelitian ini tidak ada gejala multikolonieritas karena nilai Durbin-Watson lebih dari Du dan kurang dari 4-du. Adapun ringkasan hasil pengujian terdapat pada Tabel 6 berikut.

Syarat uji normalitas, uji linieritas, uji multikolinieritas, uji heteroskedastisitas, dan uji autokorelasi terpenuhi maka dapat dilakukan uji analisis jalur. Hasil analisis jalur dapat dilihat pada diagram jalur berikut.

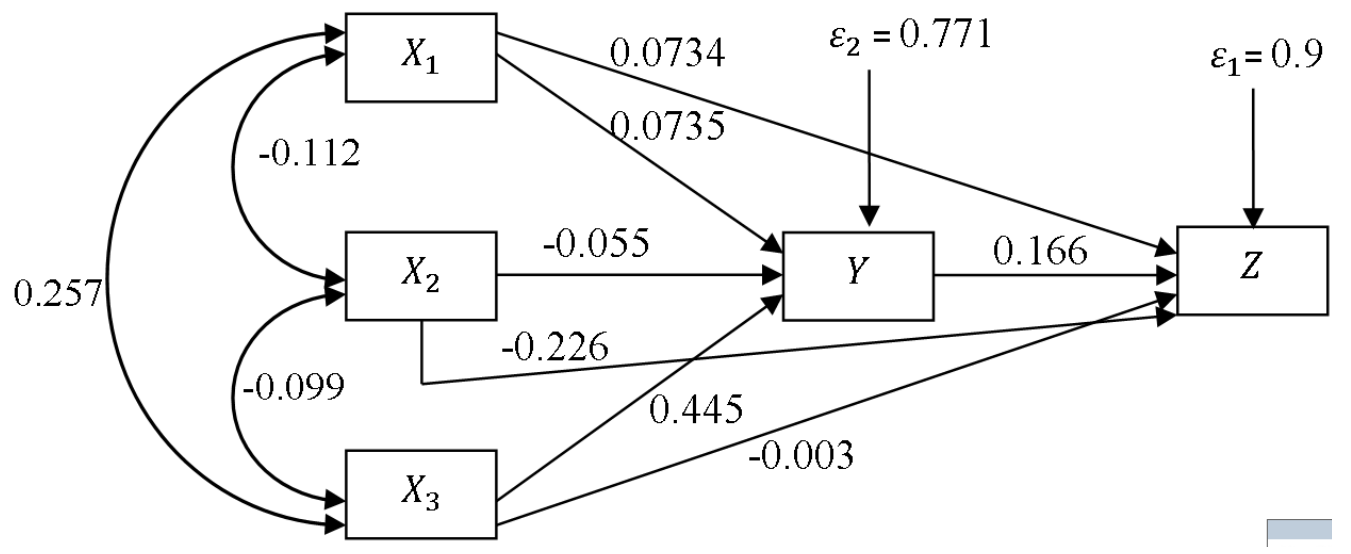

Gambar 4.6 Hasil Analisis Jalur

Hasil penelitian ini menunjukkan bahwa ada kontribusi penampilan guru dalam pembelajaran, motivasi, fasilitas dan signifikan terhadap hasil belajar matematika secara tidak langsung melalui kedisiplinan belajar, dengan kontribusi sebesar 10\%. Sedangkan sisanya 90\% dapat dipengaruhi oleh faktor lain diluar penelitian ini. Hal ini didukung dengan hasil penelitian Hasil penelitian Prasojo (2014) menyatakan bahwa ada kontribusi kedisiplinan belajar terhadap hasil belajar matematika sebesar $48.3 \%$ dan sisanya $51.7 \%$ dipengaruhi oleh variabelvariabel lain.

Adapun kontribusi penampilan guru dalampembelajaran $\left(\mathrm{X}_{1}\right)$ yang secara langsung mempengaruhi hasil belajar matematika $(\mathrm{Z})$ sebesar $0.54 \%$. Hal ini di dukung dengan 
hasil penelitian Cahyadi (2016) menyatakan bahwa ada hubungan antara motivasi dan penampilan guru terhadap hasil belajar. Motivasi belajar berkontribusi $\left(\mathrm{X}_{2}\right)$ yang secara langsung mempengaruhi hasil belajar matematika $(Z)$ sebesar $5.11 \%$, sedangkan kontribusi motivasi belajar $\left(\mathrm{X}_{2}\right)$ yang secara tidak langsung mempengaruhi hasil belajar matematika (Z) sebesar 22.1\%. Hal ini didukung dengan hasil penelitian Astuti (2012) yang menyatakan bahwa ada pengaruh yang signifikan antara motivasi belajar terhadap hasil belajar, dengan memberikan kontribusi sebesar $48.3 \%$. Hasil penelitian Satriawan (2017) menyatakan bahwa motivasi belajar secara efektif mempengaruhi hasil belajar dengan signifikansi sebesar 5\%. Hasil penelitian ini dapat dimaknai bahwa semakin tinggi motivasi belajar akan meningkatkan hasil belajar matematika siswa.

Kontribusi fasilitas belajar (X3) yang secara langsung mempengaruhi hasil belajar matematika (Z) sebesar 0.0009\%. Kontribusi kedisiplinan belajar terhadap hasil belajar matematika. Adapun kontribusi kedisiplinan belajar (Y) yang secara langsung mempengaruhi hasil belajar matematika (Z) sebesar $2.75 \%$. Hal tersebut didukung oleh penelitian Riana (2013) yang menyatakan bahwa ada pengaruh kedisiplinan belajar terhadap hasil belajar matematika dengan kontribusi sebesar $28.3 \%$. Adapun ringkasan hasil pengujian terdapat pada Tabel 7 berikut.

Hasil penelitian ini menunjukkan bahwa ada kontribusi penampilan guru dalam pembelajaran, motivasi, fasilitas dan signifikan terhadap kedisiplinan belajar, dengan kontribusi sebesar $22.9 \%$. Sedangkan sesanya $77.1 \%$ dapat dipengaruhi oleh faktor lain diluar penelitian ini. Hal ini didukung dengan hasil penelitian Muhammad Sobri (2014) tentang pengaruh kedisiplinan dan kemandirian belajar terhadap prestasi belajar memberikan kontribusi sebesar 28.1\%.

Adapun besar kontribusi penampilan guru dalam pembelajaran $\left(\mathrm{X}_{1}\right)$ yang secara langsung mempengaruhi kedisiplinan beajar (Y) sebesar 0.54\%. Kontribusimotivasi belajar $\left(\mathrm{X}_{2}\right)$ yang secara langsung mempengaruhi kedisiplinan belajar (Y) sebesar $0.302 \%$. Adapun kontribusi fasilitas belajar $\left(\mathrm{X}_{3}\right)$ yang secara langsung mempengaruhi kedisiplinan belajar (Y) sebesar 19.8\%.

Hal ini didukung dengan hasil penelitian Haryono (2016) tentang kedisiplinan belajar dan motivasi belajar memberikan kontribusi sebesar $36.3 \%$, sedangkan $63.7 \%$ dipengaruhi oleh variabel-variabel lain.

Tabel 8. Direct

\begin{tabular}{ccc}
\hline Pengaruh Variabel & $\begin{array}{c}\text { Pengaruh Kausal } \\
\text { Langsung }\end{array}$ & Sisa \\
\hline $\mathrm{X}_{1}$ Terhadap Y & & - \\
$\mathrm{X}_{2}$ Terhadap Y & & - \\
$\mathrm{X}_{3}$ Terhadap Y & & - \\
$\mathrm{X}_{1}, \mathrm{X}_{2}, \mathrm{X}_{3}$ Terhadap Y & $22.9 \%$ & $77.1 \%$ \\
\hline
\end{tabular}

Hasil penelitian ini menunjukkan bahwa ada kontribusi kedisiplinan belajar terhadap hasil belajar matematika sebesar $4.16 \%$. Sedangkan sisanya $95.84 \%$ dapat dipengaruhi oleh faktor lain diluar penelitian ini. Hal ini didukung dengan hasil penelitian Prasojo (2014) yang menyatakan bahwa kedisiplinan belajar mempengaruhi prestasi belajar sebesar $48.3 \%$ sedangkan $51.7 \%$ dipengaruhi oleh variabel-variabel lain. Hasil penelitian ini dapat dimaknai bahwa siswa yang memiliki kedisiplinan belajar yang tinggi akan memperoleh hasil belajar yang baik. 


\section{Simpulan}

Ada kontribusi penampilan guru dalam pembelajaran, motivasi, dan fasilitas terhadap hasil belajar matematika secara tidak langsung melalui kedisiplinan belajar dengan nilai signifikansi 0.011 lebih kecil dari yang berarti signifikan, dengan kontribusi sebesar $10 \%$. Sedangkan sisanya 90\% dapat dipengaruhi oleh faktor lain diluar penelitian ini. Penampilan guru dalam pembelajaran berkontribusi secara langsung terhadap hasil belajar matematika sebesar $0.54 \%$ dengan nilai signifikansi 0.412 lebih besar dari, yang berarti tidak signifikan. Motivasi belajar berkontribusi secara langsung terhadap hasil belajar matematika sebesar $5.11 \%$ dengan nilai signifikansi 0.000 lebih kecil dari , yang berarti signifikan. Motivasi belajar berkontribusi secara tidak langsung terhadap hasil belajar matematika melalui kedisiplinan belajar sebesar $22.1 \%$ dengan nilai signifikansi 0.010 lebih kecil dari, yang berarti signifikan. Fasilitas belajar berkontribusi secara langsung terhadap hasil belajar matematika sebesar $0.0009 \%$ dengan nilai signifikansi 0.000 lebih kecil dari yang berarti signifikan.
Ada kontribusi penampilan guru dalam pembelajaran, motivasi, dan fasilitas terhadap kedisiplinan belajar dengan nilai signifikansi 0.000 lebih kecil dari dengan kontribusi sebesar $22.9 \%$. Sedangkan sisanya $77.1 \%$ dapat dipengaruhi oleh faktor lain diluar penelitian ini. Penampilan guru dalam pembelajaran berkontribusi secara langsung terhadap kedisiplinan belajar sebesar $0.54 \%$, dengan nilai signifikansi 0.371 lebih besar dari yang berarti tidak signifikan. Motivasi belajar berkontribusi secara langsung terhadap kedisiplinan belajar sebesar $0.302 \%$, dengan nilai signifikansi 0.491 lebih besar dari yang berarti tidak signifikan. Fasilitas belajar berkontribusi secara langsung terhadap kedisiplinan belajar sebesar 19.8\%, dengan nilai signifikansi sebesar 0.000 lebih kecil dari yang berarti signifikan.

Ada kontribusi kedisiplinan belajar terhadap hasil belajar matematika dengan nilai signifikansi 0.021 lebih kecil dari yang berarti signifikan, dengan kontribusi sebesar $4.16 \%$. Sedangkan sisanya $95.84 \%$ dapat dipengaruhi oleh faktor lain diluar penelitian ini.

\section{Daftar Pustaka}

Astuti, Wiwin Wiji. (2012). Pengaruh Motivasi Belajar Dan Metode Pembelajaran Terhadap Hasil Belajar IPS Terpadu Kelas VIII SMP PGRI 16 Brangsong Kabupaten Kendal. Economic Education Analysis Journal, 1(2), 1-6.

Cahyadi, Rahman. (2016). Hubungan Antara Motivasi Belajar Siswa Dan Penampilan Guru Terhadap Hasil Belajar Siswa. Jurnal e-DUMath, 2(2), 233-245.

Daud, Firdaus. (2012). Pengaruh Kecerdasan Emosional (EQ) Dan Motivasi Belajar Terhadap Hasil Belajar Biologi Siswa SMA 3 Negeri Kota Palopo. Jurnal Pendidikan Dan Pembelajaran, 19(2), 243-255.

Haryono, Sugeng. (2016). Pengaruh Kedisiplinan Siswa Dan Motivasi Belajar Terhadap Prestasi Belajar Siswa Pada Mata Pelajaran Ekonomi. Faktor Jurnal Ilmiah Pendidikan, 3(3), 261-274.

Muhammad Sobri, Moerdiyanto (2014). Pengaruh Kedisiplinan Belajar Dan Kemandirian Belajar Terhadap Hasil Belajar Ekonomi Madrasah Aliyah Di Kecamatan Praya. Jurnal Harmoni Sosial, 1(1), 43-56.

Muyiwa, Adeyemi., \& Quadri, A. (2012). Influence of Universal Basic Education (UBE) Facilities on School Learning Environment in Lagos State, Nigeria. Jurnal of Education and Practice, 3(2), 30-39. 
Prasojo, Retmono Jazib. (2014). Pengaruh Perhatian Orang Tua Dan Kedisiplinan Belajar Terhadap Hasil Belajar Matematika Pelajaran IPS. Jurnal Pendidikan Ekonomi FKIP Veteran Semarang, 2(1), 1-11.

Prianto, Heri. (2013). Peningkatan Hasil Belajar Matematika Melalui Pendekatan Matematika Realistik (PMR) Siswa Kelas II-A MI Al Hikmah Geger Madiun Tahun Pelajaran 2012/2013. Jurnal Ilmiah Pendidikan, 91-104.

Riana, Rini (2013). Pengaruh Kedisiplinan Belajar Dan Kenis Kelamin Terhadap Hasil Belajar Matematika Pada Siswa SMP Negeri 1 Pucakwangi Pati Tahun Ajaran 2012/2-13. Jurnal Penelitian Pendidikan Matematika, 1-10.

Sawiji, Heri., Ridaul, I., \& Trisno, M. (2013). Pengaruh Kompetensi Guru, Motivasi Belajar Siswa, Dan Fasilitas Belajar Terhadap Prestasi Belajar Mata Pelajaran Ekonomi Pada Siswa Kelas XI IPS SMA Negeri 1 Lasem Jawa Tengah Tahun Pelajaran 2011/2012. Jurnal Pendidikan Nasional Insan Mandiri, 1(1), 1-13.

Satriawan, R. (2017). Keefektifan Model Search, Solve, Create, and Share Ditinjau dari Prestasi, Penalaran Matematis, dan Motivasi Belajar. Jurnal Riset Pendidikan Matematika, 4(1), 87-99.

Suhendri, Huri. (2011). Pengaruh Kecerdasan Matematis-Logis Dan Kemandirian Belajar Terhadap Hasil Belajar Matematika. Jurnal Formatif, 1(1), 29-39. 